\title{
Non-exhaust particulate matter emission from vehicles: A review
}

\author{
Dongdong Guo ${ }^{1,2,3, *}$, Hongyuan $\mathrm{Wei}^{4}$, Yong Guo ${ }^{4}$, Chuanqi $\mathrm{Wang}^{4}$, and Zenghui $\mathrm{Yin}^{4}$ \\ ${ }^{1}$ Beijing Institute of Technology, Beijing, 100081, China \\ ${ }^{2}$ Collaborat Innovat Ctr Elect Vehicles Beijing, Beijing, 100081, China \\ ${ }^{3}$ Beijing Vehicle Emissions Management Center, Beijing, 100176, China \\ ${ }^{4}$ China Automotive Technology and Research Center Co., Ltd.,Tianjin, 300300, China
}

Keywords: non-exhaust PM emission, brake wear PM emission, tire wear PM emission, review.

\begin{abstract}
According to the source, particulate matter produced during vehicle driving can be divided into exhaust emission and non-exhaust emission. Exhaust emission includes exhaust pipe emission and crankcase emission, while non-exhaust emission includes brake wear, tire wear, road wear and road dust. For a long time, it has been considered that the particulate matter pollution of motor vehicles mainly comes from exhaust emissions, and the control of particulate matter pollution in various countries is mainly concentrated in the tail gas. However, with the continuous tightening of emission standards, the emission of particulate matter has been reduced, but also makes the environmental pollution of non-exhaust particulate matter increasingly prominent. This paper summarizes the research on vehicle non-exhaust particulate matter emissions, aiming to emphasize the importance of non-exhaust particulate matter emissions and the necessity of legislation, so as to reduce their contribution to environmental particulate matter concentration.
\end{abstract}

\section{Introduction}

According to the source, the particulate matter produced by motor vehicle can be divided into exhaust emission source and non-exhaust emission source. The emission source of vehicle non-exhaust particulate matter includes brake wear, tire wear, road wear and road dust, among which road dust is an indirect source. It is estimated that the contribution of exhaust emission sources and non-exhaust emission sources to total $\mathrm{PM}_{10}$ emissions related to traffic is almost equal ${ }^{[1-4]}$. The research of Barlow et al. ${ }^{[5]}$ showed that, the non-exhaust particulate matter emission of China 6 gasoline vehicle was about seven times of that of exhaust particulate matter emission, and because the particulate matter of China 6 diesel vehicle equipped with DPF was very low, non-exhaust particulate matter emission has become the main source of particulate matter emission of China 6 diesel vehicle. With the increasingly stringent vehicle emission standards, the contribution of non-exhaust particulate matter emissions to the total $\mathrm{PM}_{10}$ emissions related to traffic will be further highlighted ${ }^{[6-8]}$.

*Corresponding author: weihongyuan@catacr.ac.cn 
In addition, the impact of non-exhaust particulates on human health can not be ignored. Brake wear particles contain barium, copper, antimony, iron, etc., while tire wear particles contain zinc. These heavy metals not only cause respiratory diseases, but also have cancer risk to exposed people ${ }^{[9,10]}$. Therefore, the emission of non-exhaust particulates has become the regulatory direction of emission standards in the next stage. As early as 2014, the Economic Commission for Europe (ECE) started the Legislative Study on the emission of particulate matter from brake wear, and planned to issue the official standard in 2022. However, the research on non-exhaust particulate matter emission in China is still relatively small. This paper reviews the literature research on vehicle non-exhaust particulate matter emission at home and abroad, and introduces the research status of non-exhaust particulate matter emission based on brake pad, tire and vehicle.

\section{Experimental study on non-exhaust particulate matter emission}

\subsection{Experimental study in laboratory}

\subsubsection{Research on vehicle non-exhaust particulate matter emission test based on operating loss enclosure}

Except for the California Air Resources Board (CARB), there are few reports on the indoor research of non-exhaust particulate matter emissions based on vehicle. CARB has carried out an experimental study on non-exhaust particulate matter emissions based on the whole vehicle in the operating loss chamber of chassis dynamometer ${ }^{[11]}$. During the test, the researchers kept the temperature and total volume of the chamber unchanged. The ambient air was delivered to the engine inlet through a long flexible hose, and then the vehicle exhaust was led out of the enclosure with a pipe. At the same time, the $\mathrm{CO}_{2}$ level was monitored during the test to ensure that the exhaust gas did not leak into the chamber. Through these measures to isolate the intake and exhaust, there is no exhaust tailpipe emissions in the airtight chamber. The only emissions in the airtight chamber are tire wear, brake wear, resuspended dust and evaporative emissions. The particulate matter sampler with five $\mathrm{PM}_{10}$ filters and six $\mathrm{PM}_{2.5}$ filters is used for particulate mass and chemical analysis.

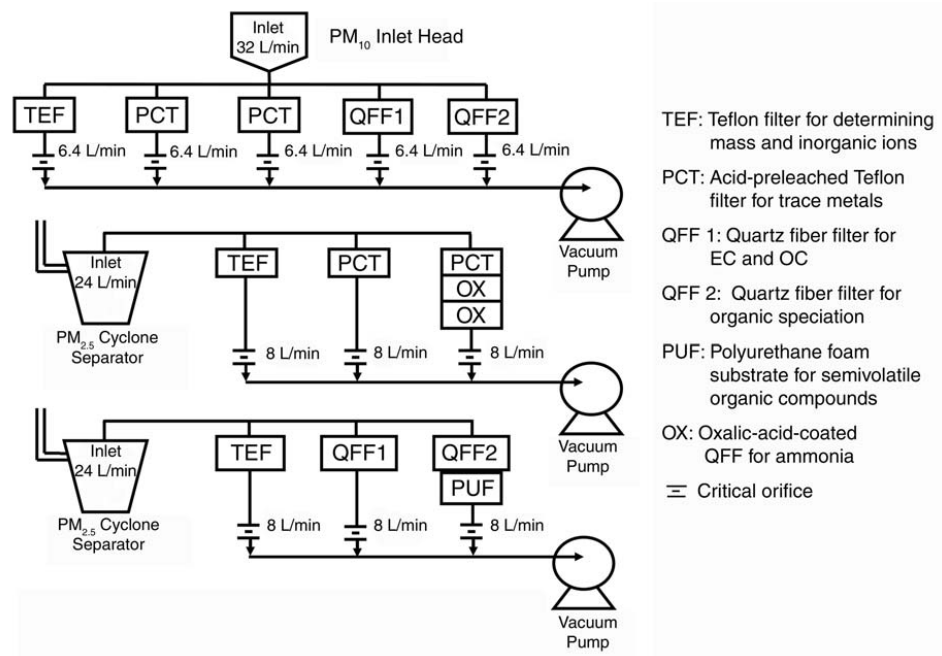

Fig. 1. Particulate matter sampling system ${ }^{[11]}$. 


\subsubsection{Research on brake wear particle emission test based on brake dynamometer}

\subsubsection{Study on mass distribution of particulate matter}

Although brake wear particles are mainly generated by mechanical processes, and coarsegrained particles are expected to be generated, many studies have shown that the concentration of fine-grained and ultra-fine-grained particles is also high ${ }^{[12-14]}$. Garg et al. ${ }^{[15]}$ carried out particle emission tests on different brake pad wear on a brake dynamometer. It was found that $86 \%$ and $63 \%$ of the particulate matter mass in $\mathrm{PM}_{10}$ and $\mathrm{PM}_{2.5}$ came from brake pad wear; $33 \%$ (by mass) of air brake wear particles distributed in the area with diameter less than $0.1 \mu \mathrm{m}$. Sanders et al. ${ }^{[16]}$ conducted a brake wear particle emission test on a brake pad dynamometer, and found that $\mathrm{PM}_{10}$ accounted for $80 \%$ of the total brake wear particle mass. Iijima et al. ${ }^{[17]}$ carried out wear test research on three different kinds of asbestos free organic brake pads, and found that $\mathrm{PM}_{2.5}$ accounted for $56 \%-70 \%$ of the total brake wear particles; SEM images showed that ultra-fine particles and some fine particles looked smoother (some of which were close to spherical) and had less sharp edges than rough particles. Therefore, these fine particles are produced by thermomechanical or thermochemical processes ${ }^{[18]}$. This may be due to that the brake wear process can cause the temperature of the brake/rotor interface to be too high, thus decomposing many brake lining materials. Therefore, some materials are likely to volatilize during braking and condense in the air flow, resulting in small particles.

1.1.2.2 Study on the quantity distribution of particulate matter

In order to understand and characterize the particles produced by brake wear, it is necessary to study their quantity size distribution. Garg et al. ${ }^{[15]}$ carried out wear particle emission test on different brake pads on a brake dynamometer, and concluded that the maximum number of particles emitted was located in the area with a diameter less than 30 $\mathrm{nm}$, which was the minimum threshold value for particle size detection by ELPI. Kukutschová et al. ${ }^{[14]}$ studied the particle size distribution of brake pad wear particles in dynamometer test of low metal brake system. Using both SMPS and APS analyzers, they found that although the small particle size $(<500 \mathrm{~nm})$ produced at low rotor temperature was negligible, the concentration of nanoparticles less than $100 \mathrm{~nm}$ increased significantly with the increase of brake disc temperature (up to $340{ }^{\circ} \mathrm{C}$ ). Based on the shape of particle size distribution and its change with time, they concluded that submicron particles $(100 \mathrm{~nm}-1 \mu \mathrm{m})$ were formed by the aggregation of primary nanoparticles through evaporation / condensation process, rather than by brake pad wear.

Not all studies have reported that the peak value of the number size distribution of brake wear particles occurs at the ultrafine particle size. Several studies have found that the number of brake wear particles has a peak at about $350 \mathrm{~nm}$. Wahlström et al. ${ }^{[18]}$ tested the low metal brake pad and non asbestos organic brake pad in clean air environment, and detected it by Grimm aerosol spectrometer. It was found that the number of brake wear particles was bimodal, with the peak values of $280 \mathrm{~nm}$ and $350 \mathrm{~nm}$. Mosleh et al. ${ }^{[19]}$ carried out wear particle emission test on semi metal brake pads of commercial trucks on brake dynamometer, and found that no matter what test parameters (sliding speed and nominal contact pressure) are, the number of brake wear particles presents a bimodal distribution, the first peak is about $350 \mathrm{~nm}$, and the second peak appears at the higher particle size $(\sim 2.0 \mu \mathrm{m})$ depending on the nominal particle size and the applied pressure.

1.1.2.3 Research on ECE legislation of brake wear particles

The PMP, which is subordinate to the ECE Working Group on pollution and energy (GRPE), established two task groups in 2014 to carry out the research on brake pad wear particle emission braking cycle and brake particle emission measurement and characterization method based on brake dynamometer. At present, the PMP working group has determined the test cycle (WLTC Novel cycle) and particulate matter sampling system, 
and completed the repeatability test of particulate matter sampling system. ECE plans to complete the draft standard in 2021 and issue a formal standard in 2022. As shown in Table 1 , it is the potential schedule of ECE brake PN emission legislation.

Table 1. Potential timetable for ECE brake PN emission legislation.

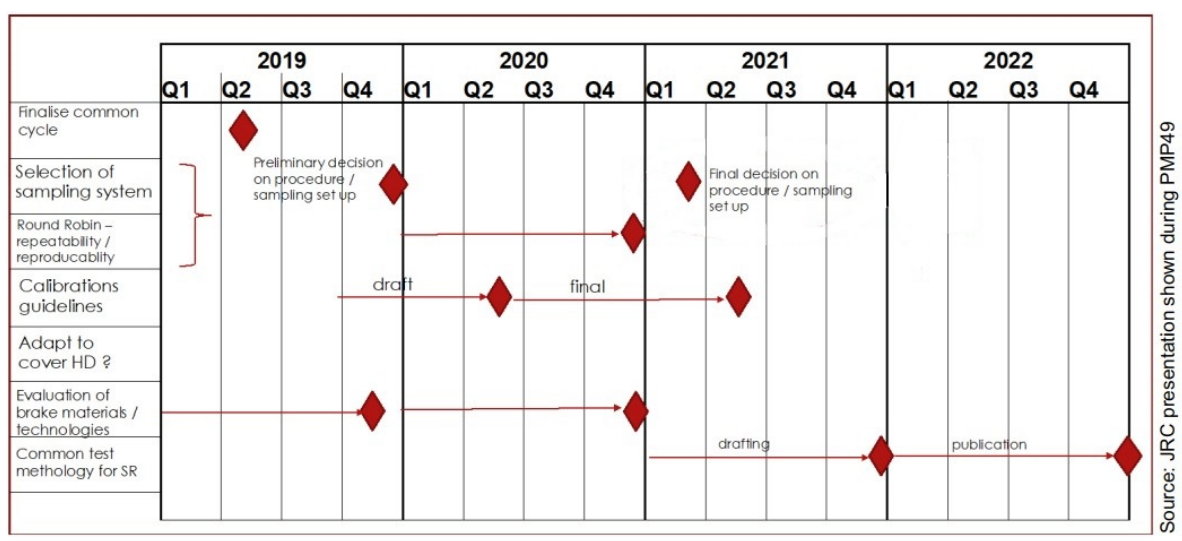

ECE released the braking test cycle (WLTC Novel cycle) in July 2018, aiming to establish a generally accepted sampling and measurement method for brake wear particles ${ }^{[20]}$. The cycle is based on the WLTP reference database, which includes in use driving data from five different world regions (EU, USA, India, Korea and Japan) with a total mileage of 740000 $\mathrm{km}$. The WLTC Novel cycle consists of 10 stages, 303 braking times, the emission test duration lasts for 4 hours and 24 minutes, and the total test mileage is $192 \mathrm{~km}$.

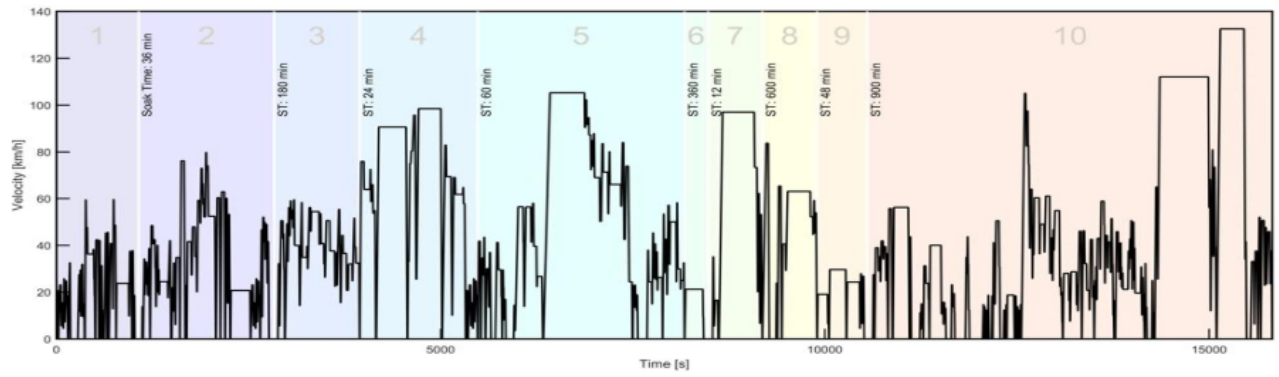

Fig. 2. Brake test cycle (WLTC-novel).

\subsubsection{Research on tire wear particle emission test based on wheel road simulator}

\subsubsection{Study on mass distribution of particulate matter}

The mechanical process involved in tire tread wear can lead to large particles (particle size greater than $20 \mu \mathrm{m})$ and coarse particles $\left(\mathrm{PM}_{2.5-10}\right)$. The thermal mechanical and thermochemical processes (thermal degradation of tire polymer, volatilization of filling oil and subsequent condensation of ultrafine particle mode materials) will also occur when the tire temperature exceeds $180{ }^{\circ} \mathrm{C}$ (extreme cornering, unusual handling and complete braking stop), which will lead to the production of fine particles and some small particles such as ultra-fine particles ${ }^{[21-23]}$. Studies have shown that less than $10 \%$ (by mass) of tire wear particles are airborne ${ }^{[23,24]}$.

Kreider et al. ${ }^{[25]}$ tested the summer tires and friction tires on the asphalt pavement on the wheel pavement simulator, and found that the particle size distribution of the collected tire wear particles ranged from $5.0 \mu \mathrm{m}$ to $220 \mu \mathrm{m}$, with a clear peak at 70-80 $\mu \mathrm{m}$. Under the normal driving conditions (steady driving, acceleration/deceleration $<2$ ), the particle size 
distribution of the collected tire-road wear particles has a peak at $50 \mu \mathrm{m}$. It should be noted that in these two experimental studies, due to the limitation of instruments, the particle size measured is less than $0.3 \mu \mathrm{m}$. Smolders et al. ${ }^{[26]}$ also conducted a similar study. They found that the average diameter of roadside tire debris was $65 \mu \mathrm{m}$ (passenger car) and $80 \mu \mathrm{m}$ (truck), which indicated that most of the substances emitted during tire wear would not stay in the air for a long time. On the other hand, tire wear particles in the air could be divided into fine particles and coarse particles according to their size.

Gustafsson et al. ${ }^{[27]}$ carried out road simulation research on friction tire and stud tire with different asphalt materials, and detected the mass size distribution of tire wear $\mathrm{PM}_{10}$ by aerodynamic particle size analyzer. The results show that the mass distribution of $\mathrm{PM}_{10}$ in friction tire is bimodal, the peak value is about 2-3 $\mu \mathrm{m}$ and $8-9 \mu \mathrm{m}$, while the mass distribution of $\mathrm{PM}_{10}$ in stud tire is single peak with peak value of 5-6 $\mu \mathrm{m}$. On the other hand, the concentration of $\mathrm{PM}_{10}$ in friction tire is significantly lower than that in stud tire. It is also found that the velocity has little effect on the shape of particle size distribution, but the total mass concentration of particles increases with the increase of velocity.

On the other hand, Kupiainen et al. ${ }^{[28]}$ carried out wear emission test of friction tire and stud tire on Asphalt Concrete Pavement on wheel pavement simulator, and found that $\mathrm{PM}_{10}$ mass size distribution was different under different tire types and speeds. Low speed (15 $\mathrm{km} / \mathrm{h}$ ) is associated with bimodal mass size distribution, at least for studded tires with bimodal peak particle size of about $1.0 \mu \mathrm{m}$ and $10 \mu \mathrm{m}$, while high speed $(30 \mathrm{~km} / \mathrm{h})$ is related to unimodal distribution, with peak particle size ranging from 9 to $10 \mu \mathrm{m}$.

1.1.3.2 Study on the quantity distribution of particulate matter

In order to understand and characterize the particles produced by tire wear, it is necessary to study the particle number distribution. Dahl et al. ${ }^{[29]}$ carried out road simulation research on different types of asphalt pavements with studs and friction tires. Although the particle size detection limit of the detector is $15 \mathrm{~nm}$, they found an obvious ultrafine particle mode, with the peak particle size between 15 and $50 \mathrm{~nm}$, and the peak particle size depends on the type of tire and pavement tested. They also found that the higher the vehicle speed, the more particles were produced, and the particle size distribution of friction tire moved toward the direction of smaller particle size (the peak particle size of friction tire was less than $20 \mathrm{~nm}$, and the maximum peak particle size of stud tire was $40 \mathrm{~nm}$ ).

Kreider et al. ${ }^{[25]}$ tested summer tires and friction tires on Asphalt Pavement in the road and laboratory, but no ultrafine particles were found under laboratory conditions. Their research includes larger wear particles. The number concentration distribution of road collected particles is single peak, and the peak particle size is about $25 \mu \mathrm{m}$, while the number concentration distribution of laboratory generated particles is bimodal, with the first peak size of $5 \mu \mathrm{m}$ and the second peak particle size of $25 \mu \mathrm{m}$. Sjödin et al. ${ }^{[30]}$ carried out wear test research on all types of tires on asphalt mastic macadam pavement. The research results show that the wear test of winter tire and summer tire does not produce ultrafine particles, only the number of wear particles of stud tire has a peak at $30 \mathrm{~nm}$.

\subsection{Experimental study outside the laboratory}

\subsubsection{Tunnel test}

The function of highway tunnel is similar to that of large-scale laboratory, and its known boundary conditions provide a good environment for researchers to quantify atmospheric particulate matter emission factors of tail gas and non tail gas sources. Since the concentration of non-exhaust emission tracers is low, and the meteorological impact in the tunnel is small, tunnel sampling has the advantage of maximizing the collection of particulate matter by selecting a shorter sampling period ${ }^{[31]}$. At present, the domestic tunnel test research mainly 
focuses on the calculation of vehicle emission factors, particle size distribution and component characteristics, while there is less research on non-exhaust particulate matter emission which has been paid more attention in recent years ${ }^{[32]}$.

Lawrence et al. ${ }^{[31,33]}$ calculated the particulate matter emission factors of vehicle exhaust and non-exhaust by combining highway tunnel (Hartfield tunnel) sampling and source apportionment model calculation. The results show that $\mathrm{PM}_{2.5}$ accounts for $66 \%$ of $\mathrm{PM}_{10}$, which is greatly affected by traffic (turbulence) and meteorological conditions; iron, copper, manganese, nickel, lead, antimony and traffic volume have good correlation; based on the source analysis model, $\mathrm{PM}_{10}$ emission factors from different sources are as following, brake wear $(3.8-4.4 \mathrm{mg} /(\mathrm{km} \cdot$ vehicle $))$ and gasoline vehicle exhaust $(3.9-4.5 \mathrm{mg} /(\mathrm{km} \cdot$ vehicle $))$, diesel vehicle exhaust $(7.2-8.3 \mathrm{mg} /(\mathrm{km} \cdot$ vehicle $))$, resuspended dust $(9-10.4 \mathrm{mg} /$ $(\mathrm{km} \cdot$ vehicle $)$ ), road wear (3.9-4.5 $\mathrm{mg} /(\mathrm{km} \cdot$ vehicle $)$ ) and unexplained emission $(7.2 \mathrm{mg} /$ $\left(\mathrm{km} \cdot\right.$ vehicle)). In the tunnel test, the non-exhaust $\mathrm{PM}_{10}$ emission factor (16.7-19.3 mg/ $(\mathrm{km} \cdot$ vehicle)) is higher than that of the vehicle fleet $(11.1-12.8 \mathrm{mg} /(\mathrm{km} \cdot$ vehicle $))$ in tunnel test. Therefore, the author emphasizes the necessity of legislation and emission reduction measures for non-exhaust particulate matter.

Hung-Lung et al. ${ }^{[34]}$ carried out a study on the particle composition characteristics of Taiwan tunnel, and found that iron, aluminum, calcium, sodium and potassium are the main elements of particulate matter, and barium is in the range of $\mathrm{PM}_{2.5-10}$. It is concluded that $\mathrm{PM}_{2.5-10}$ may be derived from road resuspension dust, brake wear and other mechanical friction particles, while $\mathrm{PM}_{2.5-10}$ mainly comes from exhaust emissions during fuel combustion and friction and wear of parts and engines.

\subsubsection{Research on real road emission test}

\subsubsection{Tire-road wear particle emission test}

The purpose of the wheel pavement simulation laboratory study is to study the contribution of tire pavement wear particles in the isolated environment under controlled laboratory conditions. However, the contribution of resuspended dust under environmental conditions is usually additionally measured in tire pavement wear particle test of actual road using mobile device ${ }^{[35]}$. Since the particles generated by the interaction between tire and road surface include tire rubber and pavement materials, the effect of tire wear on particulate matter concentration in the air may be underestimated by measuring the composition of tire rubber alone ${ }^{[36]}$. Therefore, in order to evaluate the particulate matter emission of tire wear during actual operation of vehicles, so as to better analyze urban aerosol source and evaluate $\mathrm{PM}_{2.5}$ exposure, many scholars have carried out research on tire pavement wear particulate matter emission on actual roads ${ }^{[37-42]}$. The results show that there is a positive correlation between tire-road wear particle emissions and vehicle speed, and the use of stud tires will lead to more tire-road wear particles emissions.

Pirjola et al. ${ }^{[37,38,40]}$ developed a set of collection and detection device for tire pavement wear particles and road resuspension dust for actual road vehicles. Road dust samples were collected from the rear of the left tire through a conical inlet with a surface area of $0.20 \mathrm{~m} \times$ $0.22 \mathrm{~m}$ and collected into a vertical tube with a diameter of $0.1 \mathrm{~m}$. The researchers conducted five tests in Helsinki, Finland, on dry days, on a specially designed $20 \mathrm{~km}$ route. The test results show that $\mathrm{PM}_{2.5}$ produced by tire-road wear is positively correlated with $\mathrm{PM}_{10}$, and $\mathrm{PM}$ level increases with the increase of vehicle speed; background $\mathrm{PM}_{2.5}$ is only about $6 \%$ of $\mathrm{PM}_{2.5}$ behind the tire ${ }^{[38]}$. 

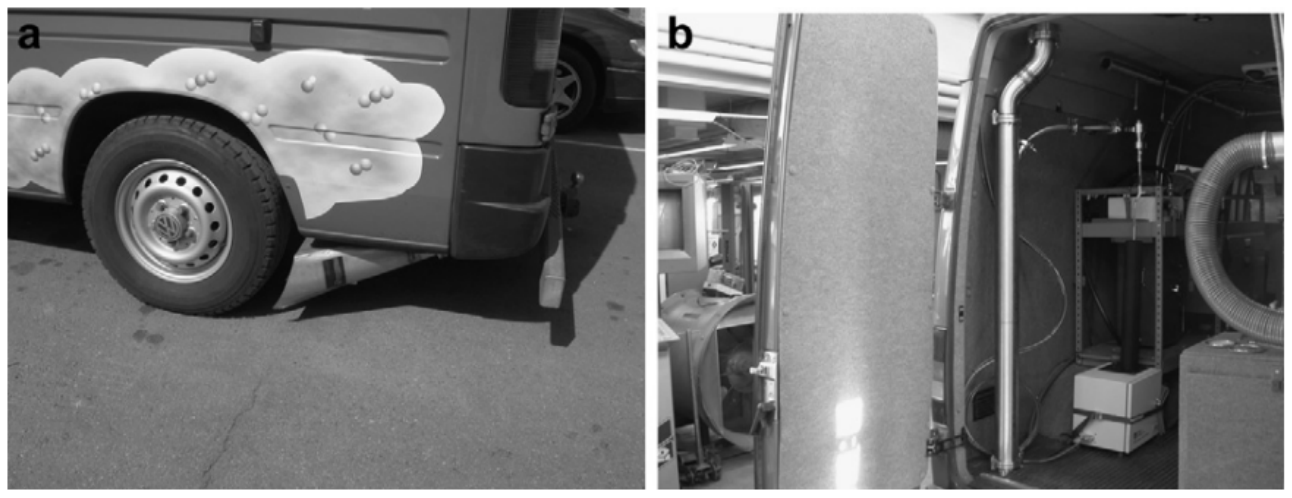

Fig. 3. Tire-road wear particulate matter emission sampling and detection device diagram ${ }^{[37] \text {. }}$

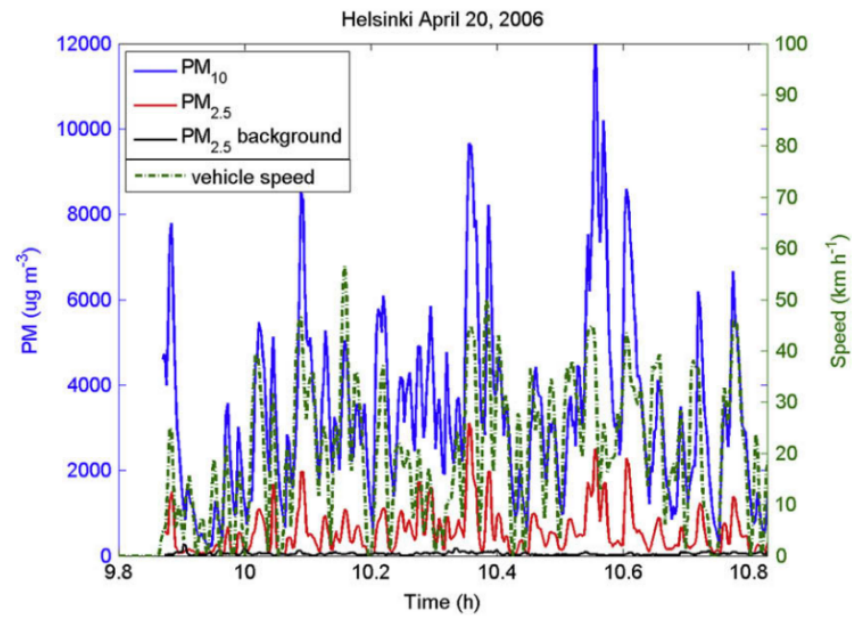

Fig. 4. Tire-road wear particle emission of test vehicle [38].

Lee et al. ${ }^{[39]}$ developed a set of tire-road wear particle emission measurement system, which can also measure brake wear particulate matter emission. The PM concentration was measured by TSI Dusttrak-DRX aerosol monitor, and the mass and size distribution of fine and ultrafine particles were measured by FMPs and APS. The researchers used the system to carry out the actual road research on tire pavement wear particulate matter emissions of test vehicles, and found that a large number of tire pavement wear particles emissions will be generated when the vehicle decelerates rapidly; because the wear of vehicle tires on asphalt pavement is higher than that on concrete pavement, the $\mathrm{PM}_{10}$ concentration and particle number generated by friction are relatively high.

Hussein et al. ${ }^{[41]}$ quantitatively analyzed the relative importance of road surface direct wear, tire type (stud tire, friction tire, summer tire), road surface type and vehicle speed on road dust emission and resuspended dust by using mobile measurement system. The results show that the tire-road wear particle emission of the vehicle with stud tire is always the highest, while the summer tire is the lowest; In May, the tire road wear particle emission of the test vehicle with stud tire at $100 \mathrm{~km} / \mathrm{h}$ was ten times higher than that at $20 \mathrm{~km} / \mathrm{h}$. However, in September, the dependence of tire-road wear particle emissions on vehicle speed is not so obvious, which may be due to less dust deposition on the road.

1.2.2.2 Brake wear particle emission test 
Farwick et al. ${ }^{[43]}$ studied the brake wear particle emission of medium-sized passenger cars when driving on a closed test track through a self-designed brake wear particle inhalation monitoring system (as shown in Figure 5). It is found that for different brake materials, the emission coefficient of $\mathrm{PM}_{10}$ is between $1.4 \mathrm{mg} /(\mathrm{km} \cdot \mathrm{brake})$ and $2.1 \mathrm{mg} /(\mathrm{km} \cdot \mathrm{brake})$, and the emission rate of one material is reduced by $18 \%$. Because the semi closed particulate sampler limits the cooling of the brake pad, the high temperature of the brake disc even exceeds $170^{\circ} \mathrm{C}$, which will lead to the generation of ultra-fine particles, resulting in a large number of particulate emissions. In the same test, the braking temperature of the vehicle in normal driving process will not exceed $153{ }^{\circ} \mathrm{C}$. Therefore, ultrafine brake particle emission is not expected to occur in normal driving process. Since it is not possible to collect all the wear particles by this method, the $\mathrm{PM}_{10}$ emission results detected by this method are smaller than those obtained by the brake dynamometer ${ }^{[15,16,44,45]}$, but the magnitude of $\mathrm{PM}_{10}$ is similar.

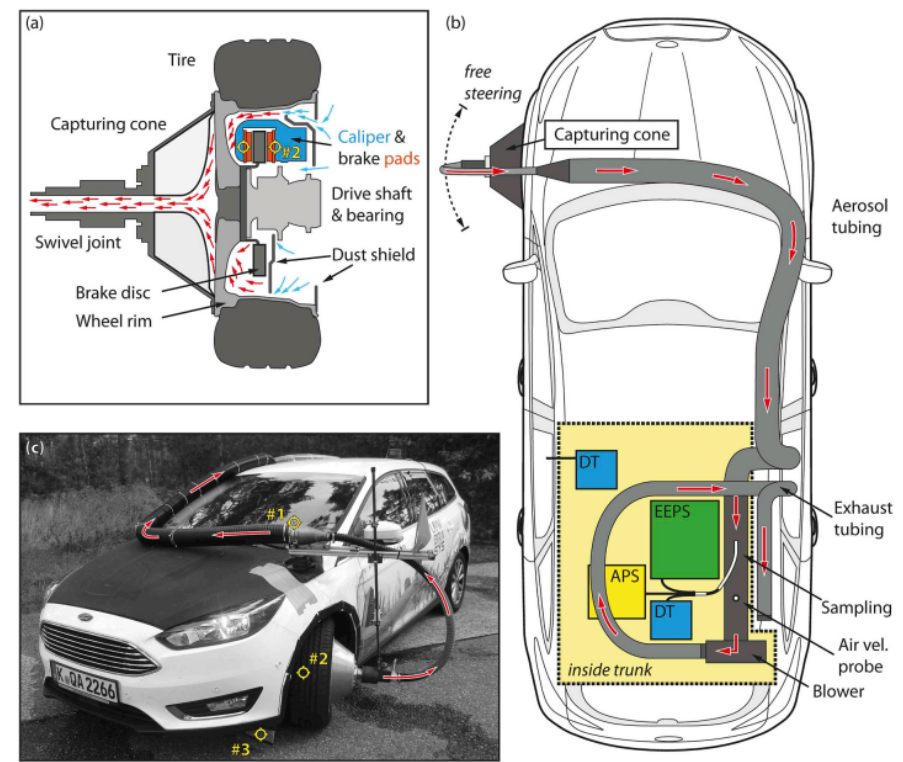

Fig. 5. Brake wear particle inhalation monitoring system ${ }^{[43]}$.

\subsubsection{Study on roadside air detection}

By determining the characteristic elements or element combination of specific non-exhaust traffic related sources, researchers can estimate the contribution of traffic non-exhaust particulate matter emissions to particulate matters in the air, and analyze the air detection at different roadside stations, which may lead to different contribution rates. Thorpe et al. ${ }^{[46]}$ analyzed the roadside air quality of a canyon road with heavy traffic in London. The results showed that the particulate matter $\left(\mathrm{PM}_{2.5-10}\right)$ generated by various wear accounted for $44 \%$ $57 \%$ of the total particulate matter emissions, of which brake wear accounted for $55 \%$, tire wear accounted for $27 \%$, and road wear accounted for $18 \%$, the suspended road dust accounts for $20 \%-22 \%$ of the total $\mathrm{PM}_{10}$ emission. The other $19 \%$ can be attributed to coarse-grained wear source emission, while the remaining $60 \%$ comes from vehicle exhaust and fine-grained wear emission.

Iron, barium, antimony, copper and other elements are widely associated with brake wear. According to the study of Geitl et al. ${ }^{[47]}$, the roadside concentrations of barium, iron, copper and antimony in the urban background in London, UK, are greatly increased, and the particle 
size distribution of these pollutants in the roadside air is very similar. Barium is used as a marker element of brake dust particles, which accounts for $1.1 \%$ of brake dust emission; iron is only caused by brake wear, accounting for $75 \%$ of brake dust emission. Bukowiecki et al. ${ }^{[48]}$ identified antimony as an element related to brake wear, and their research results showed that antimony emissions along urban street canyons were significantly lower than those measured along urban street canyons.

\section{Study on emission factors and emission inventory}

\subsection{Non-exhaust particulate matter emission factor}

\subsubsection{Emission factor of brake wear particles}

Emission Factors (EFs) are used by researchers and regulators as a tool to quantify specific pollutants emitted by a single vehicle or fleet. They can be used to predict the amount of pollutants emitted by a vehicle or a fleet of vehicles for each distance traveled, consumed a certain amount of energy or used a certain amount of fuel. EFs is usually derived for vehicle type and depends on vehicle characteristics, vehicle emission control technology, type and quality of fuel used, operating environment and operating conditions and other parameters ${ }^{[49]}$. In order to determine EFs from non-exhaust sources and their contribution to atmospheric particulate concentration, EFs can be determined either by direct measurement (including real-world test conditions and / or laboratory measurements) or by constructing receptor models ${ }^{[50]}$. Although EFs of relatively few vehicles are provided by direct measurement, they have the advantage of being carried out under very good control conditions. However, for brake wear, it is difficult to simulate the actual braking conditions under controlled test. On the other hand, receptor modeling requires an accurate understanding of the source components and assumes that the designated source contributes to the species measured in the receptor model ${ }^{[24]}$. Table 2 lists the key tracers used by researchers to identify brake wear $^{[51]}$.

Table 2. The most commonly used key tracer for brake wear particles ${ }^{[51]}$.

\begin{tabular}{cccc}
\hline Literature & Tracer & Literature & Tracer \\
\hline Adachi et al. ${ }^{[52]}, 2004$ & $\mathrm{Fe}, \mathrm{Ba}, \mathrm{Cu}, \mathrm{Sb}, \mathrm{Zr}$ & Bukowiecki et al. ${ }^{[3]}$, & $\mathrm{Fe}, \mathrm{Cu}, \mathrm{Zn}, \mathrm{Zr}, \mathrm{Mo}$, \\
Schauer et al. ${ }^{[53]}, 2006$ & $\mathrm{Fe}, \mathrm{Ba}, \mathrm{Cu}$ & Amato et al. ${ }^{[4]}, 2011$ & $\mathrm{Fe}, \mathrm{Cu}, \mathrm{Zn}, \mathrm{Cr}, \mathrm{Sn}, \mathrm{Sb}$ \\
Tanner et al. ${ }^{[54]}, 2008$ & $\mathrm{Cu}, \mathrm{Cd}$ & Apeagyei et al. ${ }^{[55]}$, & $\mathrm{Fe}, \mathrm{Ti}, \mathrm{Cu}, \mathrm{Ba}$ \\
Harrison $^{[56]}, 2009$ & $\mathrm{Ba}, \mathrm{Cu}$ & Duong et al. $.^{[57]}, 2011$ & $\mathrm{Ni}, \mathrm{Cu}$ \\
Dongarra $^{[58]}, 2009$ & $\mathrm{Cu}, \mathrm{Mo}, \mathrm{Sb}$ & Song et al. $.^{[59]}, 2011$ & $\mathrm{Sb}, \mathrm{Cu}, \mathrm{Fe}, \mathrm{Pb}$ \\
Keuken $^{[60]}, 2010$ & $\mathrm{Cu}$ & Harrison et al. ${ }^{[61]}, 2012$ & $\mathrm{Ba}, \mathrm{Cu}, \mathrm{Fe}, \mathrm{Sb}$ \\
\hline
\end{tabular}

Garg et al. ${ }^{[15]}$ conducted an emission test of particulates from commercial brake pads of light vehicles on a brake dynamometer. The results showed that the EFs of $\mathrm{PM}_{10}, \mathrm{PM}_{2.5}$ and $\mathrm{PM}_{0.1}$ were 2.9-7.5 mg/ (km· vehicle), 2.1-5.5 mg/ $(\mathrm{km} \cdot$ vehicle) and 1.2-3.1 mg/ (km·vehicle) respectively. The upper limit of the range of $\mathrm{PM}_{10}$ EFs is very close to the EPA's $7.9 \mathrm{mg} /$ $(\mathrm{km} \cdot$ vehicle), which is mainly calculated for light gasoline vehicles equipped with asbestos brakes ${ }^{[22]}$. Sanders et al. ${ }^{[16]}$ carried out tests using low metal, semi metal and non asbestos organic brake pads show that the $\mathrm{PM}_{10}$ EF of brake wear is relatively high (Table 3 ). The $\mathrm{PM}_{10}$ EFs reported by Lükewille et al. ${ }^{[62]}$ are $1.8-4.9 \mathrm{mg} /(\mathrm{km} \cdot$ vehicle $)$ for light-duty vehicles and $3.5 \mathrm{mg} /(\mathrm{km} \cdot$ vehicle) for heavy-duty vehicles respectively, while Iijima et al. [17] calculated that $\mathrm{PM}_{10}$ EFs was $5.8 \mathrm{mg} /(\mathrm{km} \cdot$ vehicle $)$ and $\mathrm{PM}_{2.5} \mathrm{EFs}$ was $3.9 \mathrm{mg} /(\mathrm{km} \cdot$ vehicle $)$. 
In general, the brake wear EFs of light vehicles measured directly are in the range of 2.0-8.0 $\mathrm{mg} /(\mathrm{km} \cdot$ vehicle $)\left(\mathrm{PM}_{10}\right)$ and 2.1-5.5 $\mathrm{mg} /(\mathrm{km} \cdot$ vehicle $)\left(\mathrm{PM}_{2.5}\right)$.

Table 3. $\mathrm{PM}_{10}$ emission factor of light vehicle braking wear in literature $(\mathrm{mg} / \mathrm{km} \cdot$ vehicle $)$.

\begin{tabular}{ccc}
\hline Literature & Research type & PM10 $_{10}$ Emission factor \\
\hline U.S. EPA ${ }^{[22]}, 1995$ & Emission inventory & 7.9 \\
Garg et al. ${ }^{[15]}, 2000$ & Experimental study on brake & $2.9 \sim 7.5$ \\
Lükewille et al. ${ }^{[62]}, 2001$ & Emission inventor & $1.8 \sim 4.9$ \\
Sanders et al. ${ }^{[16]}, 2003$ & Experimental study on brake & 8.1 \\
Luhana et al. & dynamometer & 8.8 \\
Barlow et al. ${ }^{[24]}, 2004$ & Receptor model & $4.0 \sim 8.0$ \\
Iijima et al. ${ }^{[17]}, 2008$ & Emission inventory & 5.8 \\
Bukowiecki et al. ${ }^{[3]}, 2009$ & Experimental study on brake & 8.0 \\
NAEI ${ }^{[64]}, 2012$ & dynamometer & 7.0 \\
Average value & Receptor model & 6.7 \\
\hline
\end{tabular}

Abu-Allaban et al. ${ }^{[65]}$ used chemical mass balance receptor model and scanning electron microscopy technology to determine the brake wear EFs of light and heavy vehicles on the roadside in the United States. They found that the $\mathrm{PM}_{10}$ EFs of light vehicles was 0-80 $\mathrm{mg} /(\mathrm{km} \cdot \mathrm{vehicle})$, that of heavy vehicles was $0-610 \mathrm{mg} /(\mathrm{km} \cdot$ vehicle $)$, and the corresponding $\mathrm{PM}_{2.5}$ EFs were $0-5$ and $0-15 \mathrm{mg} /(\mathrm{km} \cdot$ vehicle $)$, respectively. Generally speaking, higher EFs of brake wear particles are observed at the exit of expressway, while the emission of brake wear particles in expressway and tunnel can be ignored. According to Rauterberg-Wulff ${ }^{[66]}$, the EFs of $\mathrm{PM}_{10}$ in tunnel is very low, with $\mathrm{EF}$ of $1.0 \mathrm{mg} /(\mathrm{km} \cdot$ vehicle) for light vehicle and $24.5 \mathrm{mg} /(\mathrm{km} \cdot$ vehicle) for heavy vehicle. In order to identify the wear sources in the experimental data obtained from two different locations in Switzerland, the apart project uses positive matrix factorization (PMF) in the research process, and the results calculated by this method are more consistent with the direct measurement results.

\subsubsection{Particulate matter emission factor of tire wear}

The tire can wear out $10 \%$ of its mass during its service life ${ }^{[67]}$, while under "normal" driving conditions, $10 \%$ of the tire wear material is expected to be emitted in the form of $\mathrm{PM}_{10}{ }^{[22]}$. Speed, tire type, road surface type and driving conditions have been reported as the influencing parameters of tire wear emissions ${ }^{[27,42,51]}$. In order to determine tire wear PM EFs, the methods used include direct measurement (i.e. road sampling, road simulation study) and modeling.

Kupiainen et al. ${ }^{[28]}$ reported that $\mathrm{PM}_{10}$ EF of friction tire was $9.0 \mathrm{mg} /(\mathrm{km} \cdot$ vehicle), Sjódin et al. ${ }^{[30]}$ reported that $\mathrm{PM}_{10} \mathrm{EF}$ of summer tire was $3.8 \mathrm{mg} /(\mathrm{km} \cdot$ vehicle $)$, and $\mathrm{PM}_{10}$ emission rate in road research conducted by Panko et al. ${ }^{[68]}$ was $7.0 \mathrm{mg} / \mathrm{km}$, which was close to $\mathrm{PM}_{10}$ $\mathrm{EF}(5.0 \mathrm{mg} /(\mathrm{km} \cdot \mathrm{vehicle}))$ of light vehicles reported by EPA in the early stage, and 6.0-9.0 $\mathrm{mg} /(\mathrm{km} \cdot$ vehicle $)$ in the research by Rogge et al. ${ }^{[69]}$. On the other hand, the study of Sjödin et al. ${ }^{[30]}$ shows that the $\mathrm{PM}_{10}$ EF of stud tire is $350 \mathrm{mg} /(\mathrm{km} \cdot \mathrm{vehicle})$, and its EFs is significantly higher than that of other types of tires; the conclusion of this study is that the $\mathrm{PM}_{10}$ EFs of light vehicle friction tire measured directly is in the range of $3.8-9.0 \mathrm{mg} /(\mathrm{km} \cdot$ vehicle $)$.

Table 4. $\mathrm{PM}_{10}$ emission factor of light vehicle braking wear in literature $(\mathrm{mg} / \mathrm{km} \cdot$ vehicle).

\begin{tabular}{ccc}
\hline Literature & Research type & PM $_{10}$ Emission factor \\
\hline U.S. EPA ${ }^{[22]}, 1995$ & Emission inventory & 5.0 \\
Keuken et al. ${ }^{[70]}, 1999$ & Emission inventory & 5.0
\end{tabular}


Rauterberg-Wulff[66], 1999

Hüeglin et al. $.^{[71]}, 2000$

Lukewille et al. ${ }^{[62]}, 2001$ CEPMEIP, 2002

Luhana et al. ${ }^{[63]}, 2004$

Kupiainen et al. ${ }^{[28]}, 2005$

Ten Broeke et al. ${ }^{[72]}, 2008$

Sjödin et al. ${ }^{[30]}, 2010$

CEPMEIP $^{[73]}, 2012$

$\mathrm{NAEI}^{[64]}, 2012$

Panko et al. ${ }^{[68]}, 2013$

Average value
Receptor model

Receptor model

Receptor model

Emission inventory

Receptor model

Road simulation

experiment

Emission inventory

Road simulation experiment

Emission inventory

Emission inventory

Real road test
6.1

13

6.5

4.5

7.4

9.0

8.0

3.8

4.5

7.0

2.4

6.3

\subsection{Emission inventory study}

Timmers et al. ${ }^{[74]}$ studied the non-exhaust particulate matter emissions of different vehicle models through the existing literature, and found that there is a positive correlation between vehicle mass and non-exhaust particulate matter emission factors; the average weight of electric vehicles is $24 \%$ higher than that of the same internal combustion engine vehicles. According to Simons et al. ${ }^{[75]}$ on the impact of vehicle mass on non-exhaust particulate matter emissions and the emission factors of exhaust and non-exhaust particulates in various emission inventories, the author calculated the exhaust and non-exhaust $\mathrm{PM}_{10}$ and $\mathrm{PM}_{2.5}$ emissions of light electric vehicles, light gasoline vehicles and light diesel vehicles, as shown in table 5. The analysis shows that the increasing popularity of electric vehicles may not have a great impact on PM emission level, the non-exhaust particulate matter emission accounts for $85 \%$ - $90 \%$ of the total particulate matter emission.

Table 5.Comparison of $\mathrm{PM}_{10}$ and $\mathrm{PM}_{2.5}$ emissions of light electric vehicles, gasoline vehicles and diesel vehicles ${ }^{[74]}$

\begin{tabular}{|c|c|c|c|c|c|c|c|}
\hline \multirow{3}{*}{$\mathrm{PM}$} & \multirow{3}{*}{$\begin{array}{l}\text { Vehicle } \\
\text { technology }\end{array}$} & \multirow{2}{*}{$\begin{array}{l}\text { Exhaust } \\
\text { emission }\end{array}$} & \multicolumn{4}{|c|}{ Non-exhaust emission } & \multirow{2}{*}{$\begin{array}{c}\text { Total } \\
\text { emissions }\end{array}$} \\
\hline & & & $\begin{array}{l}\text { Tire } \\
\text { wear }\end{array}$ & $\begin{array}{l}\text { Brake } \\
\text { wear }\end{array}$ & $\begin{array}{l}\text { Road } \\
\text { wear }\end{array}$ & $\begin{array}{c}\text { Resuspended } \\
\text { dust }\end{array}$ & \\
\hline & & \multicolumn{6}{|c|}{ Unit: $\mathrm{mg} /(\mathrm{km} \cdot$ vehicle $)$} \\
\hline \multirow{3}{*}{$\mathrm{PM}_{10}$} & $\begin{array}{l}\text { Electric } \\
\text { vehicles }\end{array}$ & 0 & 7.2 & 0 & 8.9 & 49.6 & 65.7 \\
\hline & $\begin{array}{l}\text { Gasoline } \\
\text { vehicles }\end{array}$ & 3.1 & 6.1 & 9.3 & 7.5 & 40 & 66.0 \\
\hline & $\begin{array}{c}\text { Diesel } \\
\text { vehicles }\end{array}$ & 2.4 & 6.1 & 9.3 & 7.5 & 40 & 65.3 \\
\hline \multirow{3}{*}{$\mathrm{PM}_{2.5}$} & $\begin{array}{l}\text { Electric } \\
\text { vehicles }\end{array}$ & 0 & 3.7 & 0 & 3.8 & 14.9 & 22.4 \\
\hline & $\begin{array}{l}\text { Gasoline } \\
\text { vehicles }\end{array}$ & 3.0 & 2.9 & 2.2 & 3.1 & 12.0 & 23.2 \\
\hline & $\begin{array}{c}\text { Diesel } \\
\text { vehicles }\end{array}$ & 2.4 & 2.9 & 2.2 & 3.1 & 12.0 & 22.6 \\
\hline
\end{tabular}

Hao et al. ${ }^{[76]}$ used the measured data to locally modify the moves model, and calculated the emission source, particle size and composition characteristics of light vehicle particles. The analysis results show that the non-exhaust emission accounts for $72.70 \%$ of the $\mathrm{PM}_{10}$ 
emission of light-duty gasoline vehicles, and the non-exhaust emission proportion of light diesel vehicles is reduced, but it also accounts for more than $40 \%$; the $\mathrm{PM}_{10}$ and $\mathrm{PM}_{2.5}$ emissions of light-duty gasoline vehicles are $1 / 4$ of that of light diesel vehicles, $\mathrm{PM}_{10}$ and $\mathrm{PM}_{2.5}$ emissions from non-exhaust gas are the same as those of light diesel vehicles; for exhaust emissions, the particle size is mainly concentrated in $0-2.5 \mu \mathrm{m}$, and $\mathrm{PM}_{2.5}$ produced by exhaust gas of light gasoline vehicles and light diesel vehicles accounts for more than $90 \%$.

\section{Conclusions}

Based on the investigation of non-exhaust particulate matter emission at home and abroad, the following conclusions can be drawn:

1) contribution of exhaust source and non-exhaust source to traffic related $\mathrm{PM}_{10}$ is almost equal. Brake, tire and road wear and road dust resuspension have been identified as the most important non-exhaust emission related sources. The impact of brake wear on traffic related $\mathrm{PM}_{10}$ is much lower due to the significant reduction of braking times, while the contribution of tire wear is much higher in areas where studded tires are used. Due to more stringent emission control, the relative contribution of non-emission sources to traffic related emissions $\left(\mathrm{PM}_{10}\right.$ and $\left.\mathrm{PM}_{2.5}\right)$ will increase in the next few years.

2 ) is estimated that about $50 \%$ of total brake wear and $0.1 \%-10 \%$ of tire wear will emit air $\mathrm{PM}_{10}$. The rest may accumulate on or near the road or be attracted by vehicles.

3) $\mathrm{PM}_{10}$ of brake wear usually presents a single peak mass particle size distribution, and the peak value is between 2-6 $\mu \mathrm{m}$. For tire wear, some researchers have found unimodal distribution and other bimodal distribution, with one peak in the fine particles and the other between the coarse particles. In any case, a large portion of $\mathrm{PM}_{10}$ emissions from tire and brake wear are in the fine particulate fraction.

4) 0 emission factors for braking and tire wear of light vehicles have been reported, ranging from 1.0-9.0 $\mathrm{mg} /(\mathrm{km} \cdot$ vehicle) and $4.0-13 \mathrm{mg} /(\mathrm{km} \cdot$ vehicle $)$, respectively. Most studies have found that the $\mathrm{PM}_{10}$ EFs of these two sources is about $6.0-7.0 \mathrm{mg} /(\mathrm{km} \cdot$ vehicle $)$, which is very close to the Euro 5/6 diesel vehicle emission standard. The brake and tire wear of HDV PM $\mathrm{PM}_{10}$ EFs is about one order of magnitude higher than LDV. In addition, it is reported that the emission coefficient of $\mathrm{PM}_{10}$ is much higher when using studded tires. In the receptor model study, the most commonly used key tracers of brake wear are copper and antimony.

\section{Reference}

1. Theodoros G GM. Non-exhaust traffic related emissions. Brake and tyre wear PM [R].Joint Researche Centre, 2014.

2. Querol X, Alastuey A, Ruiz CR, et al.. Speciation and origin of PM10 and PM2.5 in selected European cities [J]. Atmospheric Environment, 2004, 38: 6547-6555.

3. Bukowiecki N, Gehrig R, Lienemann P, et al.. PM10 emission factors of abrasion particles from road traffic [J]. Swiss Fed. Dep. Environ. Transp. Energy Commun., 2009: $1-194$.

4. Amato F, Pandolfi M, Moreno T, et al.. Sources and variability of inhalable road dust particles in three European cities [J]. Atmospheric Environment, 2011, 45: 67776787.

5. T. B. Briefing paper on non-exhaust particulate emissions from road transport [R].Transport Research Laboratory, 2014. 
6. Winkler SL, Anderson JE, Garza L, et al.. Vehicle criteria pollutant (PM, NOx, CO, HCs) emissions: how low should we go? [J]. npj Climate and Atmospheric Science, 2018, 1.

7. Denier van der Gon H, Gerlofs-Nijland M, Gehrig R, et al.. The Policy Relevance of Wear Emissions from Road Transport, Now and in the FutureAn International Workshop Report and Consensus Statement [J]. Journal of the Air \& Waste Management Association (1995), 2013, 63: 136-149.

8. Denier Van der Gon H, Jozwicka, M., Cassee, F., et al.. The policy relevance of wear emissions from road transport. now and in the future [R].T. Report,TNO-060-UT2012-00732, 2012.

9. Gavett SH, Haykal-Coates, N., Copeland, L. B., et al.. Metal composition of ambient PM2. 5 influences severity of allergic airways disease in mice [J]. Environmental Health Perspectives, 2003, 111: 1471-1477.

10. Zhou PG, J., Zhou, X. Y., et al.. PM2.5 , PM10 and health risk assessment of heavy metals in a typical printed circuit noards manufacturing workshop [J]. Journal of Environmental Sciences, 2014, 26: 2018-2026.

11. James J S GCL, Martin M S, et al.. Characterization of metals emitted from motor vehicles [R].H.E. Institute, 2006.

12. Iijima A, Sato K, Yano K, et al.. Particle size and composition distribution analysis of automotive brake abrasion dusts for the evaluation of antimony sources of airborne particulate matter [J]. Atmospheric Environment, 2007, 41: 4908-4919.

13. Riediker M, Gasser, M., Perrenoud, A., et al.. A system to test the toxicity of brake wear particles $[\mathrm{C}] / /$ 12th International ETH-Conference on Combustion Generated Nanoparticles. Zurich, Switzerland: 2008:

14. Kukutschová J, Moravec P, Tomášek V, et al.. On airborne nano/micro-sized wear particles released from low-metallic automotive brakes [J]. Environmental Pollution, 2011, 159: 998-1006.

15. Garg BD, Cadle SH, Mulawa PA, et al.. Brake Wear Particulate Matter Emissions [J]. Environmental Science \& Technology 2000, 34: 4463-4469.

16. Sanders PG, $\mathrm{Xu} \mathrm{N}$, Dalka TM, et al.. Airborne Brake Wear Debris: Size Distributions, Composition, and a Comparison of Dynamometer and Vehicle Tests [J]. Environmental Science \& Technology, 2003, 37: 4060-4069.

17. Iijima A, Sato K, Yano K, et al.. Emission Factor for Antimony in Brake Abrasion Dusts as One of the Major Atmospheric Antimony Sources [J]. Environmental Science \& Technology, 2008, 42: 2937-2942.

18. Wahlström J, Olander, L. and Olofsson, U. Size, shape, and elemental composition of airborne wear particles from disc brake materials [J]. Tribology Letters, 2010, 38: 1524.

19. Mosleh M, Blau PJ, Dumitrescu D. Characteristics and morphology of wear particles from laboratory testing of disk brake materials [J]. Wear, 2004, 256: 1128-1134.

20. Mathissen M, Grochowicz J, Schmidt C, et al.. A novel real-world braking cycle for studying brake wear particle emissions [J]. Wear, 2018, 414-415: 219-226.

21. Fauser P. Particulate Air Pollution with Emphasis on Traffic Generated Aerosols [D]. Roskilde: Technical University of Denmark, Riso National Laboratory, 1999.

22. Boulter PG. A review of emission factors and models for road vehicle non-exhaust particulate matter [R]. Wokingham,TRL Limited, 2006. 
23. Gualtieri M, Mantecca P, Cetta F, et al.. Organic compounds in tire particle induce reactive oxygen species and heat-shock proteins in the human alveolar cell line A549 [J]. Environment International, 2008, 34: 437-442.

24. Barlow TJ, Boulter, P.G., McCrae, I.S., et al.. Non-exhaust particulate matter emissions from road traffic: Summary report [R].Scottish Executive, Welsh Assembly Government, 2007.

25. Kreider ML, Panko JM, McAtee BL, et al.. Physical and chemical characterization of tire-related particles: Comparison of particles generated using different methodologies [J]. Science of The Total Environment, 2010, 408: 652-659.

26. Smolders E, Degryse F. Fate and Effect of Zinc from Tire Debris in Soil [J]. Environmental Science \& Technology, 2002, 36: 3706-3710.

27. Gustafsson M, Blomqvist G, Gudmundsson A, et al.. Properties and toxicological effects of particles from the interaction between tyres, road pavement and winter traction material [J]. Science of The Total Environment, 2008, 393: 226-240.

28. Kupiainen KJ, Tervahattu H, Räisänen M, et al.. Size and Composition of Airborne Particles from Pavement Wear, Tires, and Traction Sanding [J]. Environmental Science \& Technology, 2005, 39: 699-706.

29. Dahl A, Gharibi A, Swietlicki E, et al.. Traffic-generated emissions of ultrafine particles from pavement-tire interface [J]. Atmospheric Environment, 2006, 40: 13141323.

30. Sjödin A, Ferm, M., Björk, A., et al.. Wear Particles from Road Traffic: A Field, Laboratory and Modelling Study [R]. Göteborg,IVL Swedish Environmental Research Institute Ltd, 2010.

31. Lawrence S, Sokhi R, Ravindra K. Quantification of vehicle fleet PM10 particulate matter emission factors from exhaust and non-exhaust sources using tunnel measurement techniques [J]. Environ Pollut, 2016, 210: 419-428.

32. Li F, Zhang Y, Jing Zhang, et al.. Characteristics of Particulate and Inorganic Elements of Motor Vehicles Based on a Tunnel Environment [J]. Environmental Science, 2015, 39: 1014-1022.

33. Lawrence S, Sokhi R, Ravindra K, et al.. Source apportionment of traffic emissions of particulate matter using tunnel measurements [J]. Atmospheric Environment, 2013, 77: $548-557$.

34. Hung-Lung $\mathrm{C}$, Yao-Sheng, $\mathrm{H}$. Particulate matter emissions from on-road vehicles in a freeway tunnel study [J]. Atmospheric Environment, 2009, 43: 4014-4022.

35. Kumar P, Pirjola L, Ketzel M, et al.. Nanoparticle emissions from 11 non-vehicle exhaust sources - A review [J]. Atmospheric Environment, 2013, 67: 252-277.

36. Dall'Osto M, Beddows, D. C. S., Gietl, J. K., et al.. Characteristics of tyre dust in polluted air: Studies by single particle mass spectrometry (ATOFMS) [J]. Atmospheric Environment, 2014, 94: 224-230.

37. Pirjola L, Parviainen H, Hussein T, et al.. "Sniffer"-a novel tool for chasing vehicles and measuring traffic pollutants [J]. Atmospheric Environment, 2004, 38: 3625 3635 .

38. Pirjola L, Kupiainen KJ, Perhoniemi P, et al.. Non-exhaust emission measurement system of the mobile laboratory SNIFFER [J]. Atmospheric Environment, 2009, 43: 4703-4713. 
39. Lee S, Kwak, J., Kim, H., et al.. Properties of roadway particles from interaction between the tire and road pavement [J]. International Journal of Automotive Technology, 2013, 14: 163-173.

40. Kupiainen KJ, Pirjola L. Vehicle non-exhaust emissions from the tyre-road interface - effect of stud properties, traction sanding and resuspension [J]. Atmospheric Environment, 2011, 45: 4141-4146.

41. Hussein T, Johansson, C., Karlsson, H., et al.. Factors affecting non-tailpipe aerosol particle emissions from paved roads: On-road measurements in Stockholm, Sweden [J]. Atmospheric Environment, 2008, 42: 688-702.

42. Mathissen M, Scheer, V., Vogt, R. , et al.. Investigation on the potential generation of ultrafine particles from the tire-road interface [J]. Atmospheric Environment, 2011, 45: 6172-6179.

43. Farwick zum Hagen FH, Mathissen M, Grabiec T, et al.. On-road vehicle measurements of brake wear particle emissions [J]. Atmospheric Environment, 2019, 217: 116943.

44. zum Hagen FHF, Mathissen M, Grabiec T, et al.. Study of Brake Wear Particle Emissions: Impact of Braking and Cruising Conditions [J]. Environmental Science \& Technology, 2019, 53: 5143-5150.

45. Perricone G, Alemani M, Metinöz I, et al.. Towards the ranking of airborne particle emissions from car brakes - a system approach [J]. Proceedings of the Institution of Mechanical Engineers, Part D: Journal of Automobile Engineering, 2016, 231: 781-797.

46. Thorpe AJ, Harrison RM, Boulter PG, et al.. Estimation of particle resuspension source strength on a major London Road [J]. Atmospheric Environment, 2007, 41: 80078020 .

47. Gietl JK, Lawrence R, Thorpe AJ, et al.. Identification of brake wear particles and derivation of a quantitative tracer for brake dust at a major road [J]. Atmospheric Environment, 2010, 44: 141-146.

48. Bukowiecki N, Lienemann P, Hill M, et al.. Real-World Emission Factors for Antimony and Other Brake Wear Related Trace Elements: Size-Segregated Values for Light and Heavy Duty Vehicles [J]. Environmental Science \& Technology, 2009, 43: 8072-8078.

49. Franco V, Kousoulidou M, Muntean M, et al.. Road vehicle emission factors development: A review [J]. Atmospheric Environment, 2013, 70: 84-97.

50. Theodoros Grigoratos GM. Non-exhaust traffic related emissions. Brake and tyre wear PM [R].European Commission, Joint Research Centre, Institute of Energy and Transport, 2014.

51. Pant P, Harrison RM. Estimation of the contribution of road traffic emissions to particulate matter concentrations from field measurements: A review [J]. Atmospheric Environment, 2013, 77: 78-97.

52. Adachi K, Tainosho Y. Characterization of heavy metal particles embedded in tire dust [J]. Environment International, 2004, 30: 1009-1017.

53. Schauer JJ LG, Shafer MM, et al.. Characterization of metals emitted from motor vehicles [R].Health Effects Institute, 2006.

54. Tanner PA, Ma H-L, Yu PKN. Fingerprinting Metals in Urban Street Dust of Beijing, Shanghai, and Hong Kong [J]. Environmental Science \& Technology, 2008, 42: 7111-7117. 
55. Apeagyei E, Bank MS, Spengler JD. Distribution of heavy metals in road dust along an urban-rural gradient in Massachusetts [J]. Atmospheric Environment, 2011, 45: 23102323.

56. Harrison RM. Airborne particulate matter from road traffic: current status of knowledge and research challenges [C]// 17th Transport and Air Pollution Symposium e 3rd Environment and Transport Symposium. 2009:

57. Duong TTT, Lee B-K. Determining contamination level of heavy metals in road dust from busy traffic areas with different characteristics [J]. Journal of Environmental Management, 2011, 92: 554-562.

58. Dongarrà G, Manno E, Varrica D. Possible markers of traffic-related emissions [J]. Environmental Monitoring and Assessment, 2008, 154: 117.

59. Song F, Gao Y. Size distributions of trace elements associated with ambient particular matter in the affinity of a major highway in the New Jersey-New York metropolitan area [J]. Atmospheric Environment, 2011, 45: 6714-6723.

60. Keuken M, Denier van der Gon H, van der Valk K. Non-exhaust emissions of PM and the efficiency of emission reduction by road sweeping and washing in the Netherlands [J]. Science of The Total Environment, 2010, 408: 4591-4599.

61. Harrison RM, Jones AM, Gietl J, et al.. Estimation of the Contributions of Brake Dust, Tire Wear, and Resuspension to Nonexhaust Traffic Particles Derived from Atmospheric Measurements [J]. Environmental Science \& Technology, 2012, 46: 65236529.

62. Lükewille A BI, Amann M, et al.. A framework to estimate the potential and costs for the control of fine particulate emissions in Europe [J]. 2001, IR-01-023.

63. Luhana L, Sokhi, R., Warner, L., et al.. Characterisation of Exhaust Particulate Emissions from Road Vehicles [R]. 2004.

64. NAEI. Road transport emission factors from 2010 NAEI [D]. http://naei.defra.gov.uk/datawarehouse/3_9_323_136259_roadtransportEFs_naei10_v2 .xls, 2012.

65. Abu-Allaban M, Gillies JA, Gertler AW, et al.. Tailpipe, resuspended road dust, and brake-wear emission factors from on-road vehicles [J]. Atmospheric Environment, 2003, 37: 5283-5293.

66. Rauterberg-Wulff A. Determination of emission factors for tyre wear particles up to $10 \mu \mathrm{m}$ by tunnel measurements $[\mathrm{C}] / /$ Proceedings of 8th International Symposium 'Transport and Air Pollution'. Graz, Austria: 1999:

67. Milani M, Pucillo FP, Ballerini M, et al.. First evidence of tyre debris characterization at the nanoscale by focused ion beam $[\mathrm{J}]$. Materials Characterization, 2004, 52: 283-288.

68. Panko JM, Chu J, Kreider ML, et al.. Measurement of airborne concentrations of tire and road wear particles in urban and rural areas of France, Japan, and the United States [J]. Atmospheric Environment, 2013, 72: 192-199.

69. Rogge WF, Hildemann LM, Mazurek MA, et al.. Sources of fine organic aerosol. 3. Road dust, tire debris, and organometallic brake lining dust: roads as sources and sinks [J]. Environmental Science \& Technology, 1993, 27: 1892-1904.

70. Keuken M, Teeuwisse, S., Ten Brink, H.M. Research on the contribution of road dust emissions to PM10 concentrations in the Netherlands [R]. Apeldoorn, The Netherlands,TNO-MEP, 1999. 
71. Hüeglin C, Gehrig, R. Contributions of Road Traffic to Ambient PM10 and PM2.5 Concentrations - Chemical Speciation of Fine Particulates and Source Attribution with a Receptor Model [R].Dübendorf Swiss Federal Laboratories for Materials Testing and Research (EMPA), 2000.

72. Ten Broeke H, Hulskotte, J., Denier van der Gon, H. Road traffic tyre wear [R].Netherlands national water board -water unit, 2008.

73. CEPMEIP. Cepmeip database [D]. http://www.air.sk/tno/cepmeip/(retrieved 31.01.14), 2012.

74. Timmers VRJH, Achten PAJ. Non-exhaust PM emissions from electric vehicles [J]. Atmospheric Environment, 2016, 134: 10-17.

75. A S. Road transport: new life cycle inventories for fossil-fuelled passenger cars and non-exhaust emissions in ecoinvent v3 [J]. Int. J. Life Cycle Assess, 2013: 1-15.

76. Yanzhao Hao, Shunxi Deng, Zhaowen Qiu, et al.. Particle sources and characteristics of light duty vehicle based on MOVES model [J]. Chinese Journal of Environmental Engineering, 2015, 9: 3915-3922. 